\title{
Exposure to titanium dioxide and other metallic oxide nanoparticles induces cytotoxicity on human neural cells and fibroblasts
}

\author{
James C K Lai' \\ Maria B Lai' \\ Sirisha Jandhyam' \\ Vikas V Dukhande' \\ Alok Bhushan' \\ Christopher K Daniels' \\ Solomon W Leung ${ }^{2}$ \\ 'Department of Biomedical \\ and Pharmaceutical Sciences, College \\ of Pharmacy, and Biomedical Research \\ Institute; ${ }^{2}$ Department of Civil \\ and Environmental Engineering, \\ College of Engineering and Biomedical \\ Research Institute, Idaho State \\ University, Pocatello, ID, USA
}

\begin{abstract}
The use of titanium dioxide $\left(\mathrm{TiO}_{2}\right)$ in various industrial applications (eg, production of paper, plastics, cosmetics, and paints) has been expanding thereby increasing the occupational and other environmental exposure of these nanoparticles to humans and other species. However, the health effects of exposure to $\mathrm{TiO}_{2}$ nanoparticles have not been systematically assessed even though recent studies suggest that such exposure induces inflammatory responses in lung tissue and cells. Because the effects of such nanoparticles on human neural cells are unknown, we have determined the putative cytotoxic effects of these nanoparticles on human astrocytes-like astrocytoma U87 cells and compared their effects on normal human fibroblasts. We found that $\mathrm{TiO}_{2}$ micro- and nanoparticles induced cell death on both human cell types in a concentrationrelated manner. We further noted that zinc oxide $(\mathrm{ZnO})$ nanoparticles were the most effective, $\mathrm{TiO}_{2}$ nanoparticles the second most effective, and magnesium oxide $(\mathrm{MgO})$ nanoparticles the least effective in inducing cell death in U87 cells. The cell death mechanisms underlying the effects of $\mathrm{TiO}_{2}$ micro- and nanoparticles on U87 cells include apoptosis, necrosis, and possibly apoptosis-like and necrosis-like cell death types. Thus, our findings may have toxicological and other pathophysiological implications on exposure of humans and other mammalian species to metallic oxide nanoparticles.

Keywords: cytotoxicity of titanium dioxide micro- and nanoparticles, cytotoxicity of zinc oxide and magnesium oxide nanoparticles, human neural cells, human fibroblasts, nanotoxicity, cell death mechanisms
\end{abstract}

\section{Introduction}

The industrial use of metallic oxide nanoparticles in a wide variety of applications has been rapidly expanding in the last decade. Such applications include the use of silicon, titanium, iron, and other metallic oxide nanoparticles, thereby increasing the occupational and other environmental exposure of these nanoparticles to humans and other species (Lai et al 2007a). Nevertheless, the health effects of exposure of humans and other species to metallic oxide nanoparticles have not been systematically investigated as their impact on the environment has not been under the scrutiny of regulatory control (Oberdorster et al 2005; Lai et al 2007b).

Titanium dioxide $\left(\mathrm{TiO}_{2}\right)$ has been increasingly employed in a variety of industrial applications including production of paper, plastics, cosmetics, and paints (Wang et al 2007) and $\mathrm{TiO}_{2}$ micro- and nanoparticles were classified as comparatively inert (Chen and Fayerweather 1988; Bernard et al 1990; Hart and Hesterberg 1998). These ubiquitous applications lead to increasing human exposure to these nanoparticles. Garabrant and colleagues (1987) noted that pleural disease was present in $17 \%$ of the workers exposed to $\mathrm{TiO}_{2}$ and was associated with the duration of work in titanium manufacturing, even though the health risk resulting from this increased exposure 
to such nanoparticles both in natural as well as industrial environments has not been comprehensively or systematically assessed. Nevertheless, recent in vivo studies in animals have pointed to the possibilities that inhalation and other lung exposure to $\mathrm{TiO}_{2}$ particles can induce inflammatory responses in lung tissue and even cytotoxicity in lung cells although the degree of inflammatory responses and cytotoxicity elicited depends critically on particle size and its surface chemistry (Rehn et al 2003; Dick et al 2003; Renwick et al 2004; Warheit et al 2005; Monteiller et al 2007; Warheit et al 2007). However, these criteria are still somewhat controversial and remain to be resolved (Renwick et al 2001; Rehn et al 2003; Monteiller et al 2007; Warheit et al 2007).

The few studies on the cytotoxic effects of $\mathrm{TiO}_{2}$ nanoparticles on human cell types have been mainly focused on lung or related epithelial cells. For example, Stearns and colleagues (2001) demonstrated human epithelial A549 cells were able to take up $\mathrm{TiO}_{2}$ nanoparticles (50 nm diameter) by endocytosis when exposed to them at $40 \mu \mathrm{g} / \mathrm{mL}$. Subsequently, Singh and colleagues (2007) found that these human lung epithelial (A549) cells could take up a range of $\mathrm{TiO}_{2}$ nanoparticles $(20-300 \mathrm{~nm}$ ) and exposure to these nanoparticles triggered inflammatory responses from the cells. In parallel, Monteiller and colleagues (2007) noted similar inflammatory responses elicited from A549 cells by exposure to $\mathrm{TiO}_{2}$ nanoparticles and exposure to $\mathrm{TiO}_{2}$ nanoparticles also induced dose-related apoptotic damage in such cells (Park et al 2007). Furthermore, anatase $\mathrm{TiO}_{2}$ nanoparticles were more cytotoxic than rutile $\mathrm{TiO}_{2}$ nanoparticles to the A549 cells (Sayes et al 2006). Exposure of BEAS-2B cells, another human bronchial epithelial cell line, to $\mathrm{TiO}_{2}$ nanoparticles likewise resulted in oxidative damage to those cells (Gurr et al 2005). Furthermore, exposure to $\mathrm{TiO}_{2}$ nanoparticles $(<100 \mathrm{~nm}$ in diameter) induced genotoxicity and cytotoxicity in cultured human lymphoblastoid (WIL2-NS) cells (Wang et al 2007).

Consistent with the findings of effects of $\mathrm{TiO}_{2}$ nanoparticles on human lung epithelial cells are the limited investigation employing non-human mammalian cells. Exposure of Syrian hamster embryo fibroblasts to ultrafine $\mathrm{TiO}_{2}$ particles $(\leq 20 \mathrm{~nm})$ resulted in micronuclei and apoptosis in those cells (Rahman et al 2002) and $\mathrm{TiO}_{2}$ nanoparticles (40 nm) also induced cytotoxicity in rat liver cells (Hussain et al 2005). Nevertheless, the effects of $\mathrm{TiO}_{2}$ nanoparticles on human or non-human mammalian neural cells are largely unknown (Lai et al 2007a, 2007b).

Airborne toxic metallic substances can enter the brain directly via retrograde transport through the olfactory nerve and olfactory bulb and/or via transport across the blood-brain barrier subsequent to lung absorption (Lai et al 2000). Astrocytes form end-feet around the brain capillary endothelium, which is the main cellular component of the blood-brain barrier (Ballabh et al 2004). Thus, metallic oxide nanoparticles could reach the brain via these two routes. Again, the putative cytotoxic effects of such nanoparticles on neural cells have not been elucidated (Lai et al 2007a, 2007b).

We hypothesized that $\mathrm{TiO}_{2}$ nanoparticles can exert differential cytotoxic effects on various human cell types. Thus, to test our hypothesis, this study was initiated to compare the putative cytotoxic effects of $\mathrm{TiO}_{2}$ micro- and nanoparticles on human astrocytoma (astrocytes-like) U87 cells and on normal human fibroblasts employing established cytotoxicity testing approaches (Rose et al 1993; Lai et al 1999, 2001; Malthankar et al 2004; Puli et al 2006; Dukhande et al 2006). Furthermore, we have compared the effects of magnesium oxide $(\mathrm{MgO})$ and zinc oxide $(\mathrm{ZnO})$ nanoparticles with those of $\mathrm{TiO}_{2}$ nanoparticles on U87 cells to determine if the effects of metallic oxide nanoparticles of essential elements (eg, $\mathrm{Mg}$ and $\mathrm{Zn}$ ) are similar to those of metallic oxide nanoparticles of nonessential elements (eg, Ti).

\section{Materials and methods Materials}

Titanium dioxide $\left(\mathrm{TiO}_{2}\right)$ microparticles (STREM Chemicals, Newburyport, MA, USA; Cat. \#93-2206; synonym, beta-Rutile; $>99 \%$ pure; $1-1.3 \mu$ ), $\mathrm{TiO}_{2}$, anatase, nanoparticles (Sigma-Aldrich, St. Louis, MO, USA; Cat. \#637254; nanopowder, $<25 \mathrm{~nm}$ particle size, $99.7 \%$ (metals basis)), $\mathrm{MgO}$ nanopowder (Sigma-Aldrich; Cat. \#549649; nanopowder, $<50 \mathrm{~nm}$ particle size), and $\mathrm{ZnO}$ nanopowder (Sigma-Aldrich; Cat. \#544906; nanopowder, $<100 \mathrm{~nm}$ particle size) were dispersed in $100 \mathrm{~mL}$ of sterile saline in a sealed conical flask and the suspension stirred at ambient temperature overnight before being employed to be diluted to the specified concentrations for treatment of cells (see below). Dulbecco's minimum essential medium (DMEM) and other chemicals (usually of analytical grade) were purchased from Sigma-Aldrich. The ApoScreen $^{\mathrm{TM}}$ Annexin V-FITC Kit (Cat. \#10010-02) was purchased from Southern Biotechnology Associates, Inc. (Birmingham, AL 35260, USA).

\section{Cells and culture conditions}

Human astrocytoma U87 (astrocytes-like) cells and human fibroblasts (HFF-1) were obtained from ATCC (Manassas, VA, USA) and were cultured in DMEM, supplemented with $10 \%(\mathrm{v} / \mathrm{v})$ (and in the case of HFF-1 cells, 15\% (v/v)) fetal 
bovine serum and were incubated at $37^{\circ} \mathrm{C}$ and $5 \%(\mathrm{v} / \mathrm{v}) \mathrm{CO}_{2}$ as described previously (Malthankar et al 2004).

\section{Cell viability assay}

Cellular viability was determined using the MTT assay (Malthankar et al 2004). Cells were seeded with equal density in each well of 96 well plates and allowed to attach to the bottom of each well for 60-90 minutes. Cells were then treated in 96-well plates with specified concentrations of $\mathrm{TiO}_{2}$ microor nanoparticles or $\mathrm{ZnO}$ nanoparticles or $\mathrm{MgO}$ nanoparticles for 48 hours at $37{ }^{\circ} \mathrm{C}$. At the end of the treatment period, MTT dye $(0.5 \%(\mathrm{w} / \mathrm{v})$ in phosphate-buffered saline) was added to each well and the plates (set one) were incubated for another 4 hours at $37^{\circ} \mathrm{C}$. Purple colored insoluble formazan crystals in viable cells were dissolved using dimethyl sulfoxide (DMSO, $100 \mu \mathrm{L}$ per well). To prevent the microand nanoparticles from interfering with this assay (data not shown), the formazan material dissolved in DMSO in each well of each plate was quantitatively transferred to an empty well in another plate (set two) while the material in DMSO from a well with micro- or nanoparticles only (ie, without cells) served as the corresponding control. Subsequently, the absorbance of the content of each well in each plate (set two) was measured at $567 \mathrm{~nm}$ using a multi-detection microplate reader (Bio-Tek Synergy HT, Winooski, VT, USA).

\section{Cellular morphology}

The putative changes in the morphology of U87 cells treated with specified concentrations of $\mathrm{TiO}_{2}$ micro- or nanoparticles for 48 hours at $37^{\circ} \mathrm{C}$ as described above were compared to that of corresponding untreated cells by light microscopy. Bright field images of cells were acquired using a Leica light microscope (Leica DM IRB, Bannockburn, IL, USA) equipped with a digital camera (Leica DFC 300FX) (Dukhande et al 2006).

\section{Cell damage and assay for necrosis}

Cell damage was determined by monitoring lactate dehydrogenase $(\mathrm{LDH})$ release from cells into the culture medium: $\mathrm{LDH}$ release from cells is a marker of necrotic cell damage and cell death (Rose et al 1993; Lai et al 1999, 2001). U87 cells were cultured in DMEM in $75 \mathrm{~cm}^{2}$ flasks until they were $\sim 70 \%$ confluent and then treated with different concentrations of $\mathrm{TiO}_{2}$ micro- or nanoparticles for 48 hours at $37^{\circ} \mathrm{C}$. Subsequently, the culture medium from each flask was removed and kept at $-70{ }^{\circ} \mathrm{C}$ until they were used for assaying LDH activity therein. LDH activity released by cells into the culture medium was assayed by the procedure of Clark and Lai (1989).

\section{Determination of necrotic}

and apoptotic cells

U87 cells were seeded at 5,000 cells per well onto a 48-well plate and were allowed 2-4 hours for them to attach to the bottom of the well. The cells were then treated with $\mathrm{TiO}_{2}$ micro- or nanoparticles at 1,10 , or $50 \mu \mathrm{g} / \mathrm{mL}$ for 48 hours at $37^{\circ} \mathrm{C}$ as described above. Then the medium was removed from each well and the cell washed with phosphate-buffered saline. Subsequently, $200 \mu \mathrm{l}$ of the binding buffer from the ApoScreen $^{\mathrm{TM}}$ Annexin V-FITC Kit (Southern Biotechnology Associates, Inc.), followed by $10 \mu \mathrm{l}$ of Annexin-V and $10 \mu \mathrm{l}$ of propidium iodide (PI) from the same kit. After adding the dyes into each well, the plate was incubated at $37^{\circ} \mathrm{C}$ for 30 minutes. Afterwards, images of fluorescent cells were captured using a fluorescence microscope (Leica DM IRB) equipped with a digital camera (Leica DFC 300 FX). The color photomicrographs were digitally converted to grey-scale images for presentation herein. The green Annexin-V dye stained apoptotic cells whereas red-fluorescent PI dye stained necrotic cells (White et al 2003).

\section{Statistical analyses of data}

Results are presented as mean \pm standard error of the mean (SEM) of 6-9 determinations in each experiment. Each experiment was performed at least three times. Data analysis was carried out by one-way analyses of variance (ANOVA), followed by post-hoc Student-Newman-Keuls test for multiple comparisons using the software KaleidaGraph version 4 (Synergy Software, Reading, PA, USA). Significance level was set at $\mathrm{P}<0.05$.

\section{Results \\ Effects of $\mathrm{TiO}_{2}$ micro- and nanoparticles on survival of human astrocytoma (astrocytes-like) U87 cells}

Exposure of U87 cells for 48 hours to both $\mathrm{TiO}_{2}$ micro- and nanoparticles at concentrations below $1.0 \mu \mathrm{g} / \mathrm{mL}$ did not affect their survival as determined by the MTT assay (Figure 1). However, at concentrations higher than $1 \mu \mathrm{g} / \mathrm{mL}$, both $\mathrm{TiO}_{2}$ micro- and nanoparticles induced concentration-related (and time-dependent up to 72 hours; data not shown) decrease in survival of U87 cells, with similar $\mathrm{IC}_{50}$ (ie, concentration that gave rise to $50 \%$ decrease in cell survival) values of $\sim 40$ and $34 \mu \mathrm{g} / \mathrm{mL}$, respectively (Figure 1). At the highest concentration of both micro- and nanoparticles employed (ie, $100 \mu \mathrm{g} / \mathrm{mL}$ ), U87 cell survival decreased to less than $30 \%$ of those of untreated cells (ie, control) (Figure 1). 


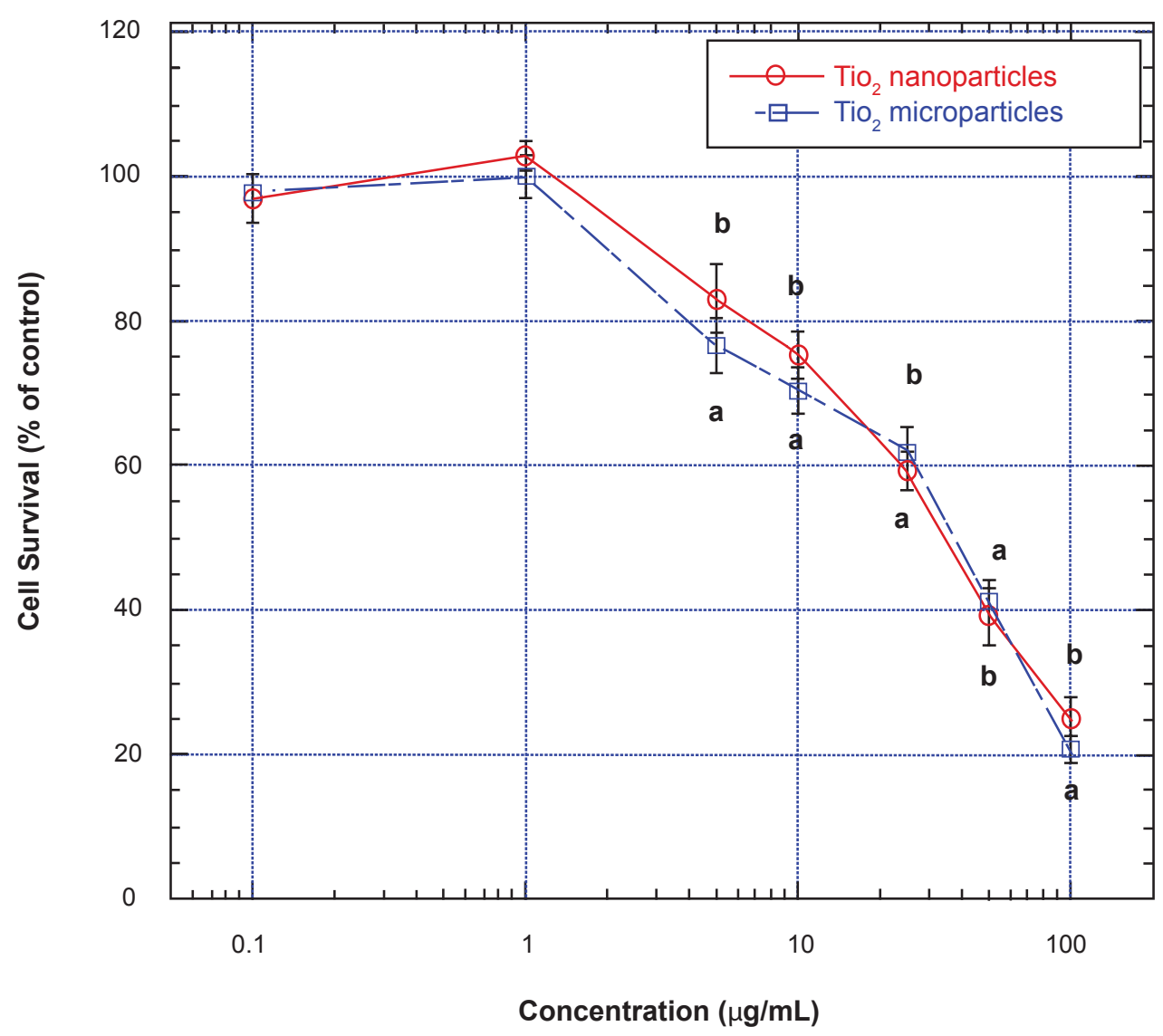

Figure I Effects of $\mathrm{TiO}_{2}$ micro- and nanoparticles on survival of human astrocytoma (astrocytes-like) U87 cells.

Notes: Values are mean \pm SEM of 6-9 determinations. U87 cells treated with $\mathrm{TiO}_{2}$ microparticles are marked with open squares and those treated with $\mathrm{TiO}_{2}$ nanoparticles are marked with open circles. Values marked with $\mathbf{a}$ and $\mathbf{b}$ are significantly different ( $\mathrm{p}<0.05$, by ANOVA and post-hoc Student-Newman-Keuls test) from corresponding mean value in control (ie, untreated) cells.

Abbreviations: ANOVA, analysis of variance; $\mathrm{SEM}$, standard error of mean; $\mathrm{TiO}_{2}$, titanium dioxide.

It is interesting to note that irrespective of their sizes, the dose-effect relations of micro- and nanoparticles on U87 cells were very similar.

\section{Effects of $\mathrm{ZnO}$ and $\mathrm{MgO}$ nanoparticles on survival of human astrocytoma (astrocytes-like) U87 cells}

To assess if other metallic oxide nanoparticles may exert cytotoxicity on human neural cells similar to those of $\mathrm{TiO}_{2}$ micro- and nanoparticles, we also studied the effects of nanoparticles of two oxides of essential metals, namely $\mathrm{ZnO}$ and $\mathrm{MgO}$, on $\mathrm{U} 87$ cells. Exposure of these cells to $\mathrm{ZnO}$ for 48 hours at concentrations higher than $1 \mu \mathrm{g} / \mathrm{mL}$ induced a concentration-related decreases in cell survival, with an $\mathrm{IC}_{50}$ of $\sim 11 \mu \mathrm{g} / \mathrm{mL}$ (Figure 2); at concentrations of $\mathrm{ZnO}$ nanoparticles higher than $20 \mu \mathrm{g} / \mathrm{mL}$, cell survival decreased to less than $5 \%$ of that of untreated (ie control) cells (Figure 2). In contrast with the effect of $\mathrm{ZnO}$ nanoparticles, treatment of U87 cells with $\mathrm{MgO}$ nanoparticles for 48 hours did not significantly decrease their survival until the concentrations were higher than $50 \mu \mathrm{g} / \mathrm{mL}$ (Figure 2). Nevertheless, even at the highest concentration employed (ie, $100 \mu \mathrm{g} / \mathrm{mL}$ ), $\mathrm{MgO}$ nanoparticles only did induce approximately $35 \%$ decrease in U87 cell survival, indicating that at the concentration range employed, $\mathrm{MgO}$ nanoparticles were less cytotoxic to these cells than $\mathrm{ZnO}$ nanoparticles (Figure 2).

\section{Effects of $\mathrm{TiO}_{2}$ micro- and nanoparticles on survival of human fibroblasts (HFF-I)}

To determine if the effects of $\mathrm{TiO}_{2}$ micro- and nanoparticles on neural cells were similar to their effects on nonneural cells, we also examined the effects of these metallic oxide microand nanoparticles on normal human fibroblasts (HFF-1 cells). Exposure of HFF-1 cells for 48 hours to both $\mathrm{TiO}_{2}$ micro- and nanoparticles induced significant decreases in cell survival at concentrations higher than $1 \mu \mathrm{g} / \mathrm{mL}$ (Figure 3). At concentrations between 1 and $10 \mu \mathrm{g} / \mathrm{mL}, \mathrm{TiO}_{2}$ nanoparticles were more potent in lowering the survival of these cells whereas when 


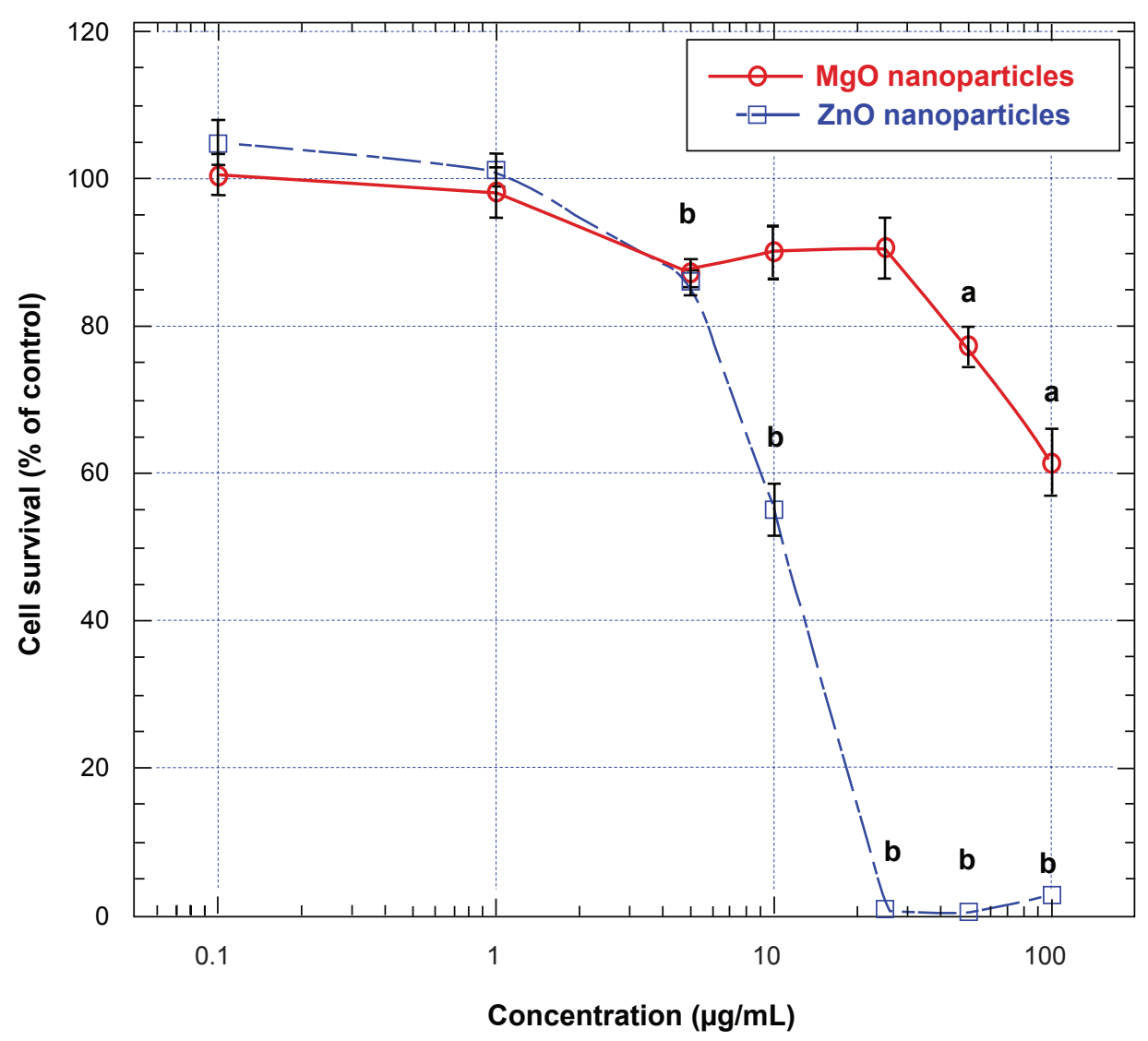

Figure 2 Effects of $\mathrm{ZnO}$ and $\mathrm{MgO}$ nanoparticles on human astrocytoma (astrocytes-like) U87 cells.

Notes: Values are mean \pm SEM of 6-9 determinations. U87 cells treated with $\mathrm{ZnO}$ nanoparticles are marked with open squares and those treated with MgO nanoparticles are marked with open circles. Values marked with $\mathbf{a}$ and $\mathbf{b}$ are significantly different $(\mathrm{p}<0.05$, by ANOVA and post-hoc Student-Newman-Keuls test) from corresponding mean value in control (ie, untreated) cells.

Abbreviations: ANOVA, analysis of variance; $\mathrm{MgO}$, magnesium oxide; $\mathrm{SEM}$, standard error of mean; $\mathrm{ZnO}$, zinc oxide.

the concentrations were increased beyond $10 \mu \mathrm{g} / \mathrm{mL}$, both the micro- and the nanoparticles were equally effective in lowering the survival of the HFF-1 cells, except at the highest level employed (ie, $100 \mu \mathrm{g} / \mathrm{mL}$ ), where again the nanoparticles were more effective than the microparticles in lowing the survival of these cells (Figure 3). When these cells were treated with $\mathrm{TiO}_{2}$ micro- and nanoparticles at $100 \mu \mathrm{g} / \mathrm{mL}$ for 48 hours, their survival decreased to less than $40 \%$ and $30 \%$, respectively, of that of untreated (ie, control) HFF-1 cells (Figure 3). Nevertheless, irrespective of their sizes, the $\mathrm{IC}_{50}$ values for both $\mathrm{TiO}_{2}$ micro- and nanoparticles in lowering the survival of HFF-1 cells were about the same: they were $\sim 40 \mu \mathrm{g} / \mathrm{mL}$ (Figure 3).

\section{Effects of $\mathrm{TiO}_{2}$ micro- and nanoparticles on lactate dehydrogenase release from human astrocytoma (astrocytes-like) \\ U87 cells into the medium}

To further elucidate the cytotoxic effects of $\mathrm{TiO}_{2}$ micro- and nanoparticles on U87 cells, we determine the effects of these two types of particles on inducing lactate dehydrogenase (LDH) release from U87 cells into the medium because LDH release from cells is a marker of necrotic cell damage and cell death (Rose et al 1993; Lai et al 1999, 2001). Treatment of $\mathrm{U} 87$ cells with $\mathrm{TiO}_{2}$ micro- or nanoparticles at 1 and $10 \mu \mathrm{g} / \mathrm{mL}$ did not induce any increases in LDH from these cells (data not shown). Treatment of these cells with $\mathrm{TiO}_{2}$ micro- or nanoparticles at $50 \mu \mathrm{g} / \mathrm{mL}$ for 48 hours only elicited modest increases $(<25 \%)$ in $\mathrm{LDH}$ release from these cells (data not shown), suggesting that even at this higher concentration, both $\mathrm{TiO}_{2}$ micro- and nanoparticles only induced minimal necrotic damage to these cells.

\section{Cell death mechanisms underlying the effects of $\mathrm{TiO}_{2}$ micro- and nanoparticles on human astrocytoma (astrocytes-like) U87 cells}

To further elucidate the cell death mechanism(s) underlying the effects of these micro- and nanoparticles on human 


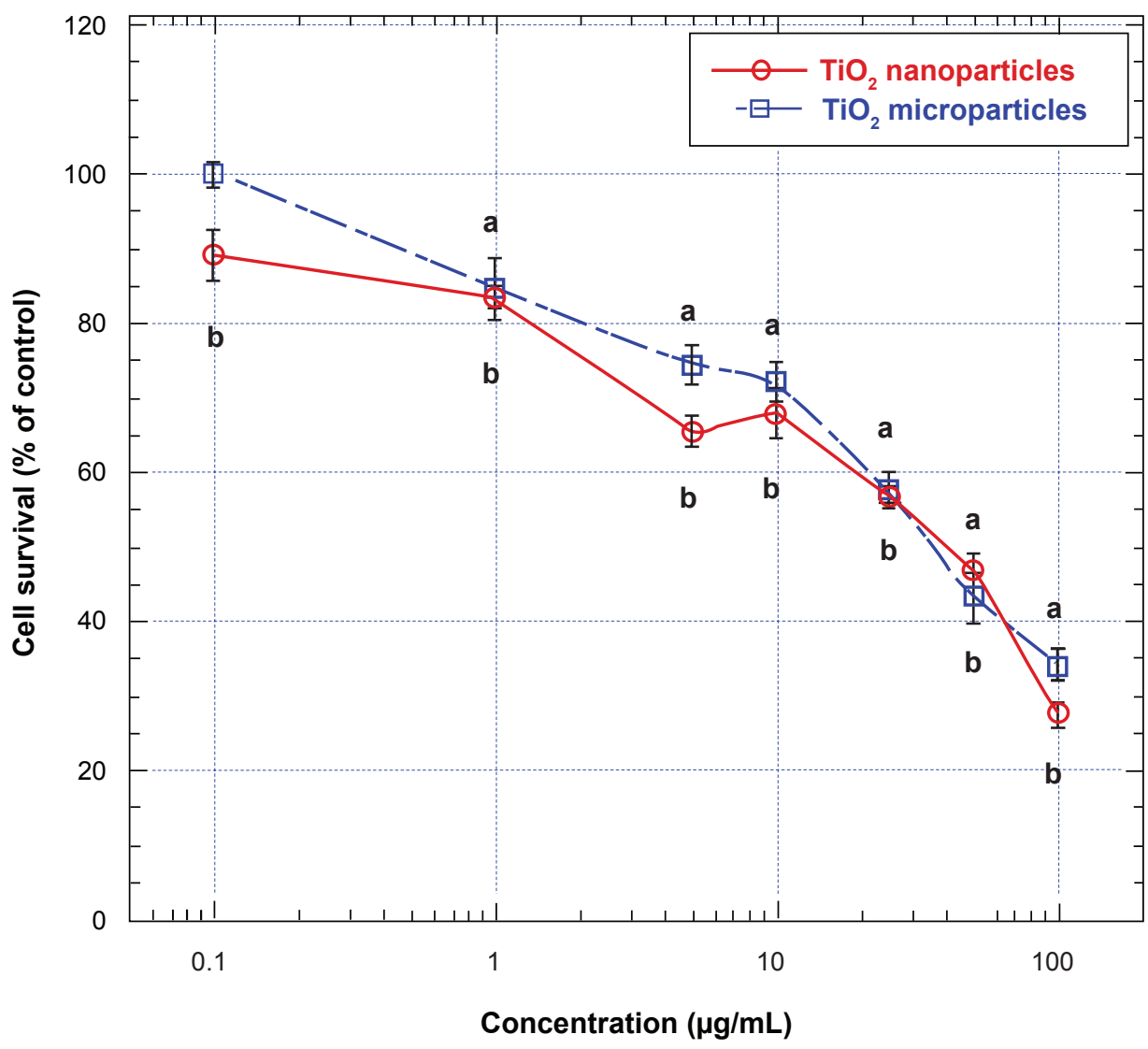

Figure 3 Effects of $\mathrm{TiO}_{2}$ micro- and nanoparticles on survival of human fibroblasts (HFF-I).

Notes: Values are mean \pm SEM of 6-9 determinations. HFF-I cells treated with $\mathrm{TiO}_{2}$ microparticles are marked with open squares and those treated with $\mathrm{TiO}_{2}$ nanoparticles are marked with open circles. Values marked with $\mathbf{a}$ and $\mathbf{b}$ are significantly different ( $\mathrm{P}<0.05$, by ANOVA and post-hoc Student-Newman-Keuls test) from corresponding mean value in control (ie, untreated) cells.

Abbreviations: ANOVA, analysis of variance; SEM, standard error of mean; $\mathrm{TiO}_{2}$, titanium dioxide.

astrocytoma (astrocytes-like) U87 cells, we examined the cellular morphology of these cells under bright field light microscopy after the cells had been exposed to specified concentration of $\mathrm{TiO}_{2}$ micro- or nanoparticles. Furthermore, employing fluorescence microscopy, we also examined the treated cells stained with PI and Annexin-V. We chose the concentrations of $\mathrm{TiO}_{2}$ micro- and nanoparticles at 1,10, and $50 \mu \mathrm{g} / \mathrm{mL}$ because they fell in the range that was above and below the respective $\mathrm{IC}_{50}$ values of the particles in inducing cell death (see Figure 1).

As noted under bright field microscopy, the control (ie, untreated) U87 cells showed "healthy" morphology with one or more processes extended from their cell bodies (Figure 4A). After treatment with either $\mathrm{TiO}_{2}$ microparticles (Figure 4B) or nanoparticles (Figure 4E) at $1 \mu \mathrm{g} / \mathrm{mL}$ for 48 hours, the nuclei of the treated U87 cells became more prominent while there were fewer processes extended from their cell bodies. At the same time, the $\mathrm{TiO}_{2}$ microparticles and nanoparticles appeared to aggregate and some aggregated on or around the U87 cells (Figures 4B and 4E). After U87 cells had been treated with 10 and $50 \mu \mathrm{g} / \mathrm{mL}$ of $\mathrm{TiO}_{2}$ microparticles (Figures 4C and 4D) or nanoparticles (Figures 4F and 4G), few intact cells were observed although some particle aggregates were noted to be around or on cells. Both micro- and nanoparticles appeared to form both small and larger aggregates, the number of which appeared to increase as the particle concentration was increased (Figures 4C, 4D, 4F, and 4G). Thus, the bright field microscopy data are consistent with cell survival data (Figure 1), suggesting that when U87 cells were treated with increasing concentrations of $\mathrm{TiO}_{2}$ microparticles or nanoparticles, there was a progressive decrease in the number of live U87 cells.

As noted under fluorescence microscopy, there were very few control (ie untreated) U87 cells stained with PI (Figure 5A), indicating that there were very few necrotic cells among the population of untreated U87 cells examined. After U87 cells had been treated with progressively increased 

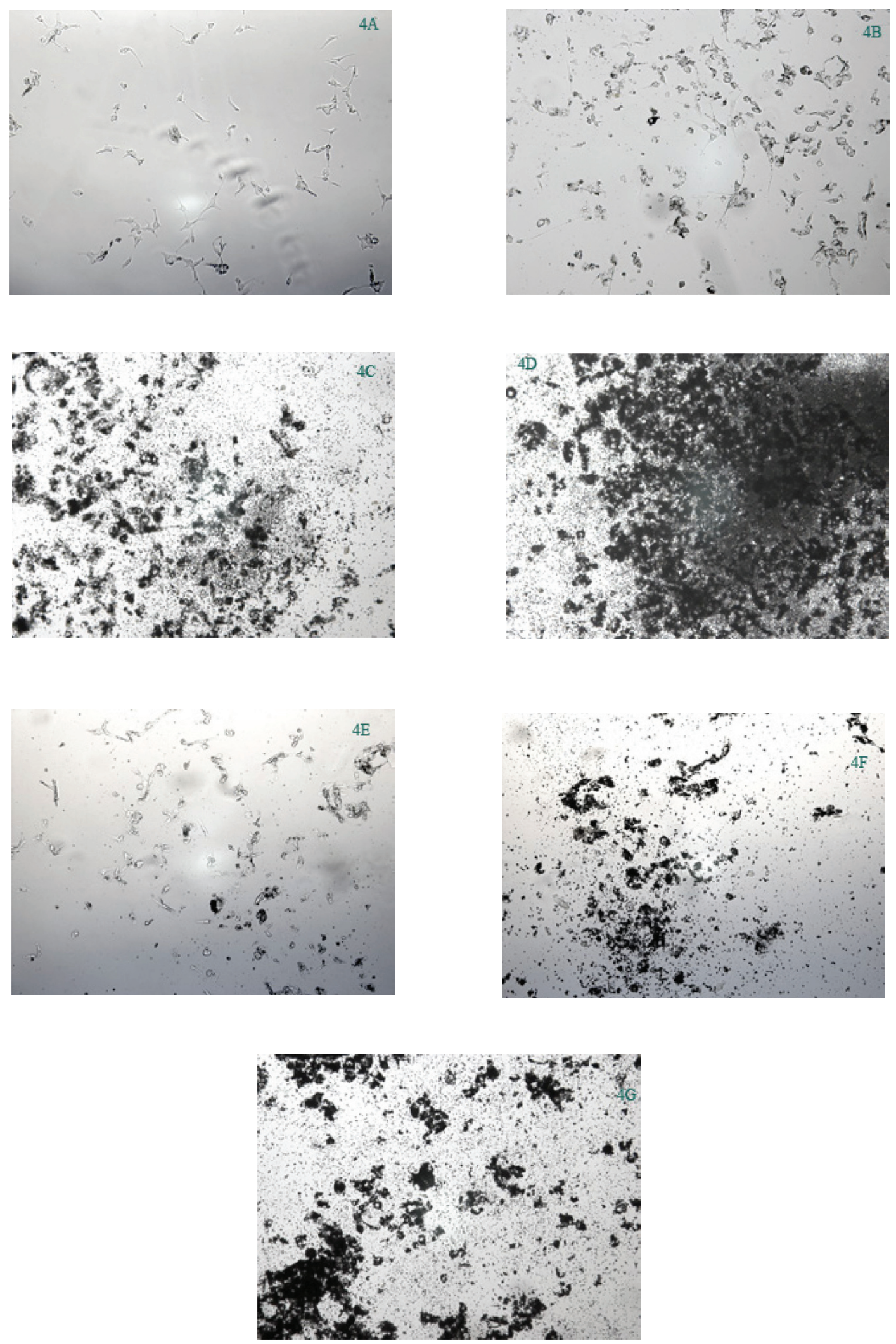

Figure 4 Cellular morphology of human astrocytoma (astrocytes-like) U87 cells after exposure to $\mathrm{TiO}_{2}$ microparticles or nanoparticles.

Notes: $\mathrm{U} 87$ cells were treated with $\mathrm{TiO}_{2}$ microparticles or nanoparticles for 48 hours and then examined with bright field light microscopy at a magnification of 100 . The treatments were: A) control (ie, untreated) U87 cells; B) cells treated with I $\mu \mathrm{g} / \mathrm{mLTiO}$, microparticles; C) cells treated with $10 \mu \mathrm{g} / \mathrm{mL}$ TiO ${ }_{2}$ microparticles; D) cells treated with $50 \mu \mathrm{g} / \mathrm{mL} \mathrm{TiO}_{2}$ microparticles; E) cells treated with I $\mu \mathrm{g} / \mathrm{mL} \mathrm{TiO}_{2}$ nanoparticles; F) cells treated with $10 \mu \mathrm{g} / \mathrm{mL} \mathrm{TiO}{ }_{2}$ nanoparticles; and $\mathbf{G}$ ) cells treated with $50 \mu \mathrm{g} / \mathrm{mL}$ $\mathrm{TiO}_{2}$ nanoparticles.

Abbreviation: $\mathrm{TiO}_{2}$, titanium dioxide. 
concentrations of $\mathrm{TiO}_{2}$ microparticles $(1,10$, or $50 \mu \mathrm{g} / \mathrm{mL})$ for 48 hours, the number of cells stained with PI progressively increased (Figures 5B-5D), suggesting that the number of necrotic cells increased with increases in treatment levels. Similarly, the number of cells stained with PI likely progressively increased (Figures 5E-5G) with increases in the treatment level of $\mathrm{TiO}_{2}$ nanoparticles $(1,10$, or $50 \mu \mathrm{g} / \mathrm{mL}$ for 48 hours) although the effects of the nanoparticles were somewhat less marked than those of the microparticles (Figures 5B-5D). It should be pointed out that we noticed that both $\mathrm{TiO}_{2}$ microparticles and nanoparticles interacted with the PI dye to yield some fluorescence in the absence of U87 cells, although their fluorescence was minimal (data not shown) compared those noted in the treated cells.

As observed under fluorescence microscopy, very few control (ie, untreated) U87 cells were stained with Annexin-V (Figure 6A), indicating that there were very few apoptotic cells within that population. After U87 cells had been treated with progressively increased concentrations of $\mathrm{TiO}_{2}$ microparticles $(1,10$, or $50 \mu \mathrm{g} / \mathrm{mL})$ for 48 hours, the number of cells stained with Annexin-V progressively increased (Figures 6B-6D), suggesting that the number of apoptotic cells increased with increases in treatment levels. It is interesting to note that not all the treated cells showed uniformed staining although the staining intensity increased as the treatment level increased (Figures 6B-6D) suggesting that the microparticle-induced apoptosis was not synchronized in those populations of U87 cells. Similarly, after U87 cells had been treated with progressively increased concentrations of $\mathrm{TiO}_{2}$ nanoparticles $(1,10$, or $50 \mu \mathrm{g} / \mathrm{mL})$ for 48 hours, the number of cells stained with Annexin-V progressively increased (Figures 6E-6G), suggesting that the number of apoptotic cells increased with increases in treatment levels. However, the level of Annexin-V staining in the nanoparticles-treated cells was less marked compared to those in cells treated with corresponding levels of microparticles (Figures 6B-6D). Again, we noticed that both $\mathrm{TiO}_{2}$ microparticles and nanoparticles interacted with the Annexin- $\mathrm{V}$ dye to yield some fluorescence in the absence of U87 cells, although their fluorescence was minimal (data not shown). Furthermore, it was interesting to observe that many U87 cells treated with $\mathrm{TiO}_{2}$ microparticles or nanoparticles stained with Annexin-V also co-stained with PI (compare Figures 5 and 6) while in the same field there were few treated cells that stained only with Annexin-V or PI, suggesting either apoptosis and necrosis mechanisms were cooccurring in those cells or those cells exhibited another cell death mechanism that shares some common features with apoptosis and necrosis (ie, hybrid mechanism; Bröker et al 2005; Wei et al 2006; Golstein and Kroemer 2007).

\section{Discussion}

To our knowledge our studies are the first to demonstrate the cytotoxic effects of $\mathrm{TiO}_{2}$ micro- and nanoparticles on human neural cells (namely U87 astrocytoma cells) and to compare those effects with the effects of $\mathrm{ZnO}$ and $\mathrm{MgO}$ nanoparticles on the same cell type. At the same time we also contrasted the cytotoxic effects of $\mathrm{TiO}_{2}$ micro- and nanoparticles on human U87 cells (astrocytes-like) and on normal human fibroblasts (HFF-1 cells). Furthermore, we have also determined the cell death mechanisms underlying the cytotoxic effects of $\mathrm{TiO}_{2}$ micro- and nanoparticles on U87 cells. We found that $\mathrm{TiO}_{2}$ micro- and nanoparticles appeared to induce U87 cells to undergo both apoptosis and necrosis or a cell death mechanism that may contain features of both apoptosis and necrosis (see below).

Because the putative cytotoxic effects of $\mathrm{TiO}_{2}$ micro- and nanoparticles on human cells (especially human neural cells) have not been systematically elucidated, with the exception of human lung epithelial (A549) cells (Stearns et al 2001; Singh et al 2007; Monteiller et al 2007; Park et al 2007), we have examined the effects of $\mathrm{TiO}_{2}$ micro- and nanoparticles on human astrocytoma (astrocytes-like) U87 cells and normal human fibroblasts (HFF-1 cells) employing the MTT cell survival assay (Lai et al 1999, 2001; Malthankar et al 2004; Puli et al 2006; Dukhande et al 2006). Our results demonstrate that in a concentration range similar to those employed in human lung (A549) cells (Stearns et al 2001), treatment of human astrocytoma (astrocytes-like) U87 cells with $\mathrm{TiO}_{2}$ microparticles or nanoparticles at levels higher than $1 \mu \mathrm{g} / \mathrm{mL}$ for 48 hours induced a concentration-related lowering of cell survival, with $\mathrm{IC}_{50}$ values of $30-40 \mu \mathrm{g} / \mathrm{mL}$ (Figure 1). At the highest level of both $\mathrm{TiO}_{2}$ microparticles and nanoparticles investigated (ie, $100 \mu \mathrm{g} / \mathrm{mL}$ ), the survival of U87 cells decreased to less than 30\% (Figure 1). Similarly, exposure of normal human fibroblasts (HFF-1 cells) to both $\mathrm{TiO}_{2}$ microparticles and nanoparticles in the same concentration range also induced a dose-related decrease in cell survival, with $\mathrm{IC}_{50}$ values of $\sim 40 \mu \mathrm{g} / \mathrm{mL}$ (Figure 3 ) although at the lower concentration range of 1 to $10 \mu \mathrm{g} / \mathrm{mL}, \mathrm{TiO}_{2}$ nanoparticles were more effective than the microparticles in lowering the survival of human fibroblasts (HFF-1 cells) (Figure 3). Thus, these results suggest that both $\mathrm{TiO}_{2}$ microparticles and nanoparticles, despite the difference in their sizes, are equally effective in inducing cell death in human neural (ie, U87) cells and normal fibroblasts (Figures 1 and 3). While the 

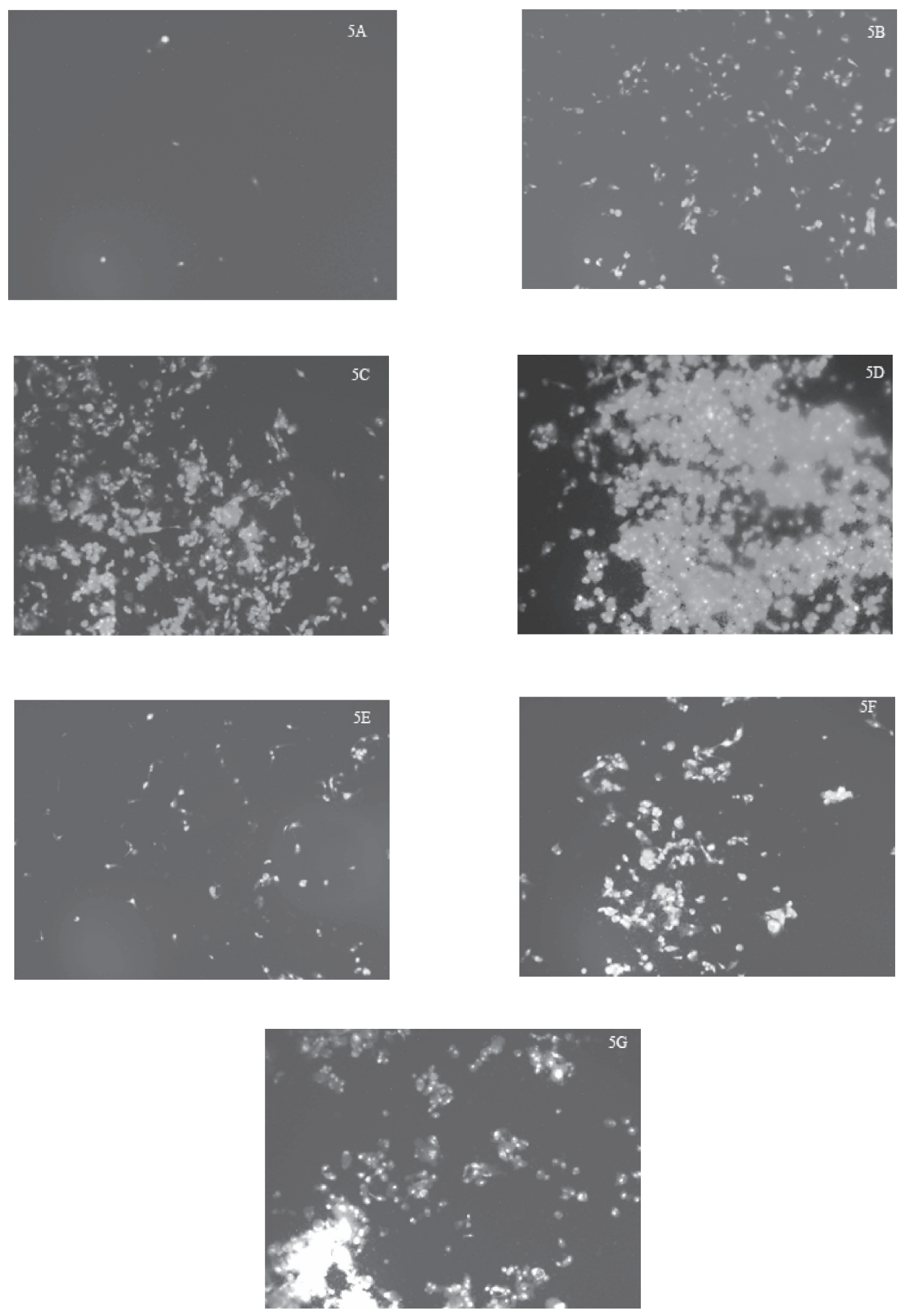

Figure 5 Increases in Pl-stained cells after exposure of human astrocytoma (astrocytes-like) U87 cells to TiO ${ }_{2}$ microparticles or nanoparticles.

Notes: $U 87$ cells were treated with $\mathrm{TiO}_{2}$ microparticles or nanoparticles for 48 hours, then stained with PI, and the stained cells were photographed at a magnification of 100.The treatments were: $\mathbf{A}$ ) control (ie, untreated) $\mathrm{U} 87$ cells; B) cells treated with I $\mu \mathrm{g} / \mathrm{mL} \mathrm{TiO}{ }_{2}$ microparticles; C) cells treated with I0 $\mu \mathrm{g} / \mathrm{mL}$ TiO ${ }_{2}$ microparticles; $\mathbf{D}$ ) cells treated with $50 \mu \mathrm{g} / \mathrm{mL} \mathrm{TiO}_{2}$ microparticles; E) cells treated with I $\mu \mathrm{g} / \mathrm{mL} \mathrm{TiO}$, nanoparticles; F) cells treated with $10 \mu \mathrm{g} / \mathrm{mL} \mathrm{TiO}_{2}$ nanoparticles; and $\left.\mathbf{G}\right)$ cells treated with $50 \mu \mathrm{g} / \mathrm{mLTiO}_{2}$ nanoparticles.

Abbreviations: $\mathrm{PI}$, propidium iodide; $\mathrm{TiO}_{2}$, titanium dioxide. 

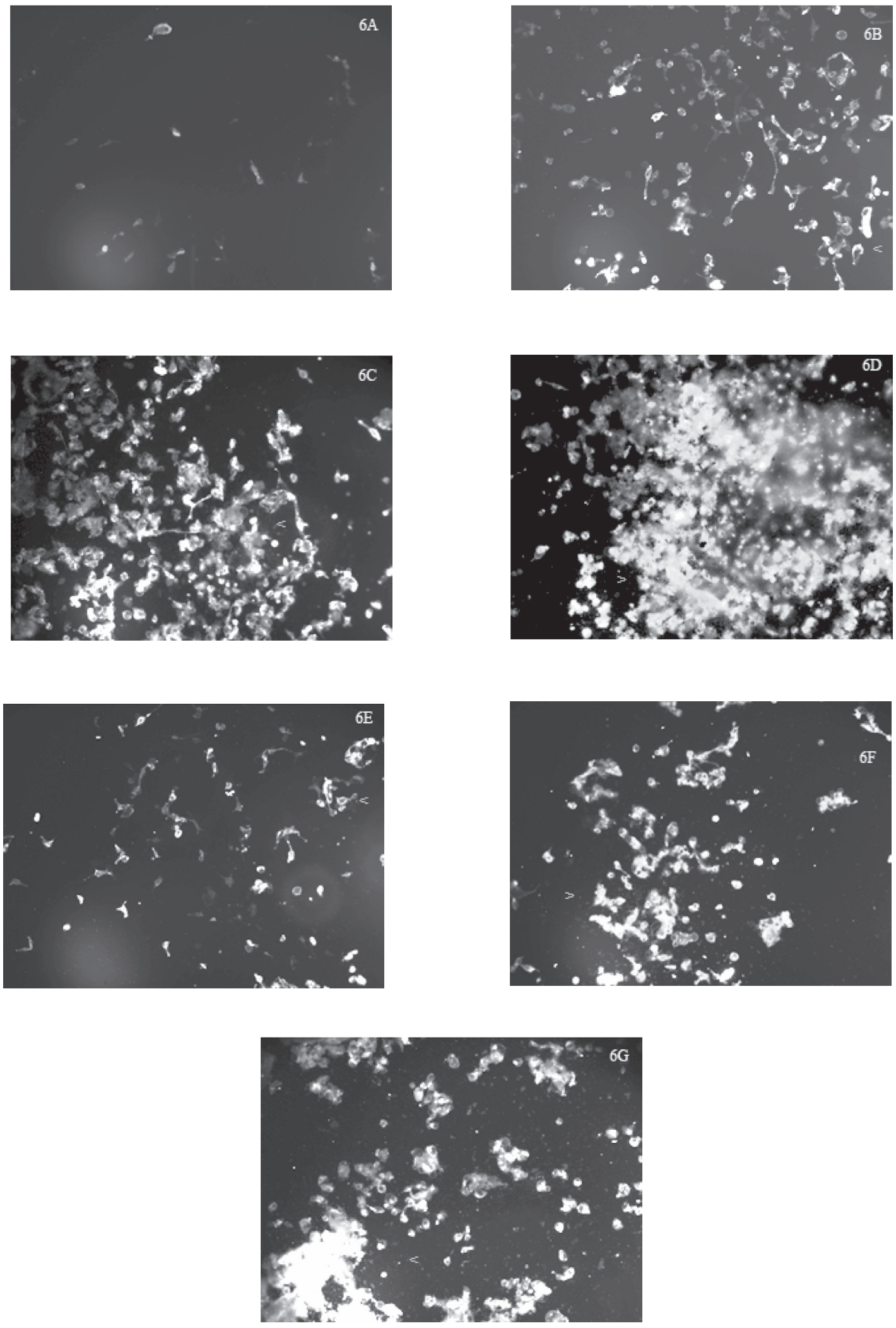

Figure 6 Increases in Annexin-V-stained cells after exposure of human astrocytoma (astrocytes-like) U87 cells to TiO ${ }_{2}$ microparticles or nanoparticles.

Notes: $U 87$ cells were treated with $\mathrm{TiO}_{2}$ microparticles or nanoparticles for 48 hours, then stained with Annexin- $\mathrm{V}$, and the stained cells were photographed at a magnification of 100. The treatments were: A) control (ie, untreated) U87 cells; B) cells treated with I $\mu \mathrm{g} / \mathrm{mL} \mathrm{TiO}$ microparticles; C) cells treated with $10 \mu \mathrm{g} / \mathrm{mL} \mathrm{TiO}$, microparticles; D) cells treated with $50 \mu \mathrm{g} / \mathrm{mL} \mathrm{TiO}_{2}$ microparticles; E) cells treated with I $\mu \mathrm{g} / \mathrm{mL} \mathrm{TiO}{ }_{2}$ nanoparticles; $\mathbf{F}$ ) cells treated with $10 \mu \mathrm{g} / \mathrm{mL} \mathrm{TiO}{ }_{2}$ nanoparticles; and $\mathbf{G}$ ) cells treated with $50 \mu \mathrm{g} / \mathrm{mL} \mathrm{TiO}$, nanoparticles. Cells marked with $<$ or $>$ were co-stained with both Annexin-V and $\mathrm{PI}$

Abbreviations: $\mathrm{Pl}$, propidium iodide; $\mathrm{TiO}_{2}$, titanium dioxide. 
cytotoxic effects of $\mathrm{TiO}_{2}$ microparticles and nanoparticles on human cell types other than those discussed above are largely unknown, there is one study noting that exposure to $\mathrm{TiO}_{2}$ nanoparticles induced cytotoxicity and genotoxicity in human lymphoblastoid (WIL2-NS) cells (Wang et al 2007). Furthermore, Hussain and colleagues (2005) reported $\mathrm{TiO}_{2}$ nanoparticles induced cytotoxicity in rat liver cells.

As far as we are aware, we are also the first to compare the cytotoxic effects of metallic oxide nanoparticles of essential metals (namely zinc and magnesium) with those of a nonessential metal (ie, Ti) on human neural (namely U87 astrocytoma) cells. It is interesting to note that of the three metallic oxide nanoparticles, $\mathrm{ZnO}$ nanoparticles were the most effective (Figure 3 ), $\mathrm{TiO}_{2}$ nanoparticles were the next most effective (Figure 1), and $\mathrm{MgO}$ nanoparticles the least effective (Figure 3) in inducing cell death in U87 cells. In this context, it is relevant to observe that, in contrast with their effect on human neural U87 cells, $\mathrm{ZnO}$ nanoparticles $(\sim 13 \mathrm{~nm})$ are not effective in lowering the survival of primary human T cells at concentrations $\leq 5 \mathrm{mM}$ (Reddy et al 2007). Clearly, additional work is required to further elucidate the cytotoxic effects of $\mathrm{ZnO}$ and other metallic oxide nanoparticles on these and other human cell types.

Because cell death mechanisms underlying the effects of $\mathrm{TiO}_{2}$ microparticles and nanoparticles on neural cells are unknown, we have investigated these putative mechanisms in human astrocytoma (astrocytes-like) U87 cells. We found that a fraction of $\mathrm{U} 87$ cells treated with $\mathrm{TiO}_{2}$ microparticles or nanoparticles showed Annexin-V staining, a marker of apoptosis, and the cellular staining was increased with increases in the treatment concentrations of the microparticles or nanoparticles (Figure 6). This finding indicates that treatment of U87 cells with either $\mathrm{TiO}_{2}$ microparticles or nanoparticles, irrespective of their sizes, induces apoptosis in those cells: this observation is consistent with that of Park and colleagues (2007) who showed that treatment of human lung epithelial (A549) cells with $\mathrm{TiO}_{2}$ nanoparticles induce dose-related apoptotic damage in those cells.

In our studies (Figure 5), we also noted that a fraction of U87 cells treated with $\mathrm{TiO}_{2}$ microparticles or nanoparticles showed PI staining, a marker of necrosis, and the cellular staining was increased with increases in the treatment concentrations of the microparticles or nanoparticles (Figure 5). Thus, this observation demonstrates that treatment with $\mathrm{TiO}_{2}$ microparticles or nanoparticles also induces necrotic cell death in human neural (ie, U87) cells. However, a third and larger fraction of $\mathrm{U} 87$ cells treated with $\mathrm{TiO}_{2}$ microparticles or nanoparticles showed co-staining with both PI and Annexin-V (compare Figures 5 and 6). There are several mechanistic explanations to account for the co-staining of PI and Annexin-V in the treated U87 cells. (i) Both apoptosis and necrosis could be co-occurring in the U87 cells treated with $\mathrm{TiO}_{2}$ microparticles or nanoparticles. Co-existence of apoptosis and necrosis in neural cells is known to occur: for example, in the developing brain, focal ischemia induces cell death with overt apoptotic characteristics co-existing with some features of necrosis (Wei et al 2006). (ii) Paraptosis, a new type of cell death independent of caspases (Sperandio et al 2000; Bröker et al 2005), could occur in the U87 cells treated with $\mathrm{TiO}_{2}$ microparticles or nanoparticles because paraptotic cells are stained with PI (Sperandio et al 2000). (iii) The apoptosis-like and necrosis-like programmed cell death as postulated by Bröker and colleagues (2005) could occur in the U87 cells treated with $\mathrm{TiO}_{2}$ microparticles or nanoparticles because of our observation that the cells were co-stained with PI and Annexin-V, yet the lactate dehydrogenase release from such cells were minimal (see Results section above). (iv) There remains the possibility that we may be encountering a totally new mode of cell death mechanism in the $\mathrm{U} 87$ cells treated with $\mathrm{TiO}_{2}$ microparticles or nanoparticles. After all, it has become increasingly clear that the "classical" distinction of three cell death types - type I (apoptosis), type II (autophagy), and type III (necrosis) - is inadequate to account for all the observed phenomena of cell death (Bröker et al 2005; Golstein and Kroemer 2007). Consequently, only additional studies will elucidate as to which of the cell death mechanisms proposed above can accurately depict the mechanisms induced in U87 cells by treatment with $\mathrm{TiO}_{2}$ microparticles or nanoparticles.

\section{Conclusion and implications}

Our studies are the first to demonstrate that exposure of human neural (ie, astrocytoma U87) cells to $\mathrm{TiO}_{2}$ micro- and nanoparticles induces a concentration-related increases in cell death in this cell type. We also found similar dose-related effects of these micro- and nanoparticles in inducing cell death in normal human fibroblasts (HFF-1 cells). In comparing the effects of metallic oxide nanoparticles of essential metals (ie, $\mathrm{ZnO}$ and $\mathrm{MgO}$ ) and nonessential metals (ie, $\mathrm{TiO}_{2}$ ), we noted $\mathrm{ZnO}$ nanoparticles are the most effective, $\mathrm{TiO}_{2}$ nanoparticles the second most effective, and $\mathrm{MgO}$ nanoparticles the least effective in inducing decreases in survival of human neural (ie astrocytoma U87) cells.

We observed that treatment of human astrocytoma (astrocytes-like) U87 cells with $\mathrm{TiO}_{2}$ microparticles or nanoparticles induces several modes of cell death in these cells, 
including apoptosis, necrosis, and possibly a "new" type of cell death that is apoptosis-like and necrosis-like. Thus, these interesting phenomena merit further investigation to elucidate the underlying pathophysiological and molecular mechanisms.

As alluded to above, the industrial use of metallic oxide nanoparticles (including those of $\mathrm{TiO}_{2}$ ) in wide diversity of applications has been expanding exponentially, leading to increasing occupational and other environmental exposure of these nanoparticles to human and other species. Because airborne toxic metallic substances can enter the brain directly via retrograde transport through the olfactory nerve into the rest of the brain and/or via transport across the blood-brain barrier, the results of our studies may have toxicological and other pathophysiological implications in exposure of human and other mammalian species to $\mathrm{TiO}_{2}$ micro- and nanoparticles in particular, and to metallic oxide nanoparticles in general. Consequently, metallic oxides such as $\mathrm{TiO}_{2}$, that is used in dental and other implants (Wennerberg et al 1995; Rasmusson et al 2005) because the material appears to be biologically compatible, may not be as benign as one previously presupposed. Clearly, this area of nanotoxicity deserves further systematic investigation.

\section{Acknowledgments}

Our studies were supported by an USAMRMC Project Grant (Contract \#W81XWH-07-2-0078) and NIH Grant \#P20 RR016454 from the Idaho INBRE Program of the National Center for Research Resources.

\section{References}

Ballabh P, Braun A, Nedergaard M. 2004. The blood-brain barrier: an overview: structure, regulation, and clinical implications. Neurobiol Dis, 16:1-13.

Bernard BK, Osheroff MR, Hofmann A, et al. 1990. Toxicology and carcinogenesis studies of dietary titanium dioxide-coated mica in male and female Fischer 344 rats. J Toxicol Environ Health, 29:417-29.

Bröker LE, Kruyt FAE, Giaccone G. 2005. Cell death independent of caspases: a review. Clin Cancer Res, 11:3155-62.

Chen JL, Fayerweather WE. 1988. Epidemiologic study of workers exposed to titanium dioxide. J Occup Med, 30:937-42.

Clark JB, Lai JCK. 1989. Glycolytic, tricarboxylic acid cycle, and related enzymes in brain. In: Boulton AA, Baker GB, Butterworth RF (ed). NeuroMethods, Vol. 11. Clifton, NJ: Humana Press. p. 233-81.

Dick CA, Brown DM, Donaldson K, et al. 2003. The role of free radicals in the toxic and inflammatory effects of four different ultrafine particle types. Inhal Toxicol, 15:39-52.

Dukhande VV, Malthankar-Phatak GH, Hugus JJ, et al. 2006. Manganese induced neurotoxicity is differentially enhanced by glutathione depletion in astrocytoma and neuroblastoma cells. Neurochem Res, 31: 1349-1357.

Garabrant DH, Fine LJ, Oliver C, et al. 1987. Abnormalities of pulmonary function and pleural disease among titanium metal production workers. Scand J Work Environ Health, 13:47-51.

Golstein P, Kroemer G. 2007. Cell death by necrosis: towards a molecular definition. Trends Biochem Sci, 32:37-43.
Gurr JR, Wang AS, Chen CH, et al. 2005. Ultrafine titanium dioxide particles in the absence of photoactivation can induce oxidative damage to human bronchial epithelial cells. Toxicology, 213:66-73.

Hart GA, Hesterberg TW. 1998. In vitro toxicity of respirable-size particles of diatomaceous earth and crystalline silica compared with asbestos and titanium dioxide. J Occup Environ Med, 40:29-42.

Hussain SM, Hess KL, Gearhart JM, et al. 2005. In vitro toxicity of nanoparticles in BRL 3A rat liver cells. Toxicol In Vitro, 19:975-83.

Lai JCK, Nguyen JV, White BK, et al. 1999. Manganese induces apoptosis in B cell hybridoma, PC12, neuroblastoma, and astrocytoma cells. Mol Biol Cell, 10(Suppl):445a.

Lai JCK, Minski MJ, Chan AWK, et al. 2000. Interrelations between manganese and other metal ions in health and disease. In: Sigel A, Sigel H (ed). Metal ions in biological systems. New York: Marcel Dekker, p. 123-56.

Lai JCK, White BK, Chiu AF-C, et al. 2001. Manganese induces cell death in primary cultures of neurons and astrocytes and in cultured neuroblastoma and astrocytoma cells. FASEB J, 15(\#4, Pt. 1):A221.

Lai JCK, Lai MB, Edgley KL, et al. 2007a. Silicon dioxide nanoparticles can exert cytotoxic effects on neural cells. Proceedings of 2007 Nanotechnology Conference and Trade Show, Volume 2, Chapter 8: Bio Materials and Tissues: p. 741-3.

Lai JCK, Schoen MP, Perez Gracia A, et al. 2007b. Prosthetic devices: challenges and implications of robotic implants and biological interfaces. Proc I Mech E, Vol 221 Part H, J Engineering in Medicine, Special Issue entitled: "Micro and Nano Technologies in Medicine:" p. 173-183.

Malthankar GV, White BK, Bhushan A, et al. 2004. Differential lowering by manganese treatment of activities of glycolytic and tricarboxylic acid cycle enzymes in neuroblastoma and astrocytoma cells is associated with manganese-induced cell death. Neurochem Res, 29:709-17.

Monteiller C, Tran L, MacNee W, et al. 2007. The pro-inflammatory effects of low-toxicity low-solubility particles, nanoparticles and fine particles, on epithelial cells in vitro: the role of surface area. Occup Environ Med, 64:609-15.

Oberdorster G, Maynard A, Donaldson K, et al. 2005. ILSI research foundation/risk science institute nanomaterial toxicity screening working group. Principles for characterizing the potential human health effects from exposure to nanomaterials: elements of a screening strategy. Particle Fibre Toxicol, 2:2-8.

Park S, Lee YK, Jung M, et al. 2007. Cellular toxicity of various inhalable metal nanoparticles on human alveolar epithelial cells. Inhal Toxicol, 19(Suppl 1):59-65.

Puli S, Lai JCK, Edgley KL, et al. 2006. Signaling pathways mediating manganese-induced neurotoxicity in human glioblastoma cells (U87). Neurochem Res, 31:1211-8.

Rahman Q, Lohani M, Dopp E, et al. 2002. Evidence that ultrafine titanium dioxide induces micronuclei and apoptosis in Syrian hamster embryo fibroblasts. Environ Health Perspect, 110:797-800.

Rasmusson L, Roos J, Bystedt H. 2005. A 10-year follow-up study of titanium dioxide-blasted implants. Clin Implant Dent Rel Res, 7:36-42.

Reddy KM, Feris K, Bell J, et al. 2007. Selective toxicity of zinc oxide nanoparticles to prokaryotic and eukaryotic systems. Appl Phys Lett, 90:213902.

Rehn B, Seiler F, Rehn S, et al. 2003. Investigations on the inflammatory and genotoxic lung effects of two types of titanium dioxide: untreated and surface treated. Toxicol Appl Pharmacol, 189:84-95.

Renwick LC, Donaldson K, Clouter A. 2001. Impairment of alveolar macrophage phagocytosis by ultrafine particles. Toxicol Appl Pharmacol, 172:119-27.

Renwick LC, Brown D, Clouter A, et al. 2004. Increased inflammation and altered macrophage chemotactic responses caused by two ultrafine particle types. Occup Environ Med, 61:442-7.

Rose K, Goldberg MP, Choi DW. 1993. Cytotoxicity in murine neocortical cell culture. Methods Toxicol, 1A:46-60.

Sayes CM, Wahi R, Kurian PA, et al. 2006. Correlating nanoscale titania structure with toxicity: a cytotoxicity and inflammatory response study with human dermal fibroblasts and human lung epithelial cells. Toxicol Sci, 92:174-85. 
Singh S, Shi T, Duffin R, et al. 2007. Endocytosis, oxidative stress and IL-8 expression in human lung epithelial cells upon treatment with fine and ultrafine $\mathrm{TiO}_{2}$ : role of the specific surface area and of surface methylation of the particles. Toxicol Appl Pharmacol, 222:141-51.

Stearns RC, Paulauskis JD, Godleski JJ. 2001. Endocytosis of ultrafine particles by A549 cells. Am J Respir Cell Mol Biol, 24:108-15.

Wang JJ, Sanderson BJ, Wang H. 2007. Cyto- and genotoxicity of ultrafine $\mathrm{TiO}_{2}$ particles in cultured human lymphoblastoid cells. Mutat Res, 628:99-106.

Warheit DB, Brock WJ, Lee KP, et al. 2005. Comparative pulmonary toxicity inhalation and instillation studies with different $\mathrm{TiO}_{2}$ particle formulations: impact of surface treatments on particle toxicity. Toxicol Sci, 88:514-24.
Warheit DB, Webb TR, Reed KL, et al. 2007. Pulmonary toxicity study in rats with three forms of ultrafine- $\mathrm{TiO}_{2}$ particles: differential responses related to surface properties. Toxicology, 230:90-104.

Wei L, Han BH, Li Y, et al. 2006. Cell death mechanism and protective effect of erythropoietin after focal ischemia in the Whisker-Barrel cortex of neonatal rats. $J$ Pharmacol Exp Ther, 317:109-16.

Wennerberg A, Albrektsson T, Andersson B, et al. 1995. A histomorphometric and removal torque study of screw-shaped titanium implants with three different surface topographies. Clin Oral Implants Res, 6:24-30.

White MG, Emery M, Nonner D, et al. 2003. Caspase activation contributes to delayed death of heat-stressed striatal neurons. $J$ Neurochem, 87:958-68. 